\title{
MODEL FOR FAIR TRAVELING OF FAMILIES WITH CHILDREN AFFECTED BY BEHAVIORAL DISTURBS
}

\author{
Liga Danilane \\ Rezekne Academy of Technologies, Latvia
}

\begin{abstract}
Often, parents of children with special needs choose not to venture anywhere. They frequently avoid travels since they are unaware of how to get the accommodations they need during the journey. On the other hand, companies that offer travel services, especially microcompanies, don't know the needs of families with children with special needs.

The research was carried out within the project "Eliminating Social Inclusion" EliSE Nr. 20191-LV01-KA204-060427. The principal objective of the EliSE project is supporting parents of children with behavioral disturbs realizing an educational parent-training module for "fair traveling" in European countries and an educational toolkit.

Accordingly, the primary target group of this project is represented by social educators that will be trained on how to train parents of children with behavioral disturbs (parent-training).

Keywords: Fair traveling, parents of children with behavioural disturbs, social educator, special education.
\end{abstract}

\section{Introduction}

The impact of the economic crisis in European countries affects directly and indirectly vulnerable groups including families of children with special needs. Negative prejudices weaken the effort of integrating children with behavioral disturbs preventing them from having equal participation in community life.

Often, parents of children with special needs choose not to venture anywhere. They frequently avoid travels since they are unaware of how to get the accommodations they need during the journey. On the other hand, companies that offer travel services, especially micro-companies, don't know the needs of families with children with special needs.

Families with children of disabilities have a much closer interpersonal dynamic that need to be carefully considered in the context of traveling. When considering leisure opportunities for children with disabilities, family members play an important role since the children in general spend more time interacting with family members than their typically developing peers (Buttimer \& Tierney, 2005)

The article is created within the framework of the Erasmus + Strategic Partnership program project "Eliminating Social Exclusion" EliSE Nr. 2019-1LV01-KA204-060427. 
The principal objective of the EliSE project is supporting parents of children with behavioral disturbs realizing an educational parent-training module for "fair traveling” in European countries and an educational toolkit.

The Project Consortium is formed of six partners from six different countries: Latvia - Rezekne Academy of Technologies, Italy - Ecoistituto del Friuli Venezia Giulia, Poland - Pedagogiczna Im.Janusza Korczaka w Warszawie, Bulgaria - National Association of Municipal Clerks in Bulgaria, Greece Interdisciplinary Network of Special and Intercultural Education INCLUDE, and Turkey - Saricam Halk Egitimi Merkezi.

Project partners performed the desk research in their countries collecting various available online and offline sources (such as scientific literature, reports, statistics, recommendations) checking for their reliability. On the basis of the desk research results, the fair traveling model for families with children with behavioral disorders/disturbances has been developed, identifying its most important dimensions, needs, and issues these families can experience in traveling. 4 parents having children with behavioral disorders and 3 educators from each project partner country participated in the focus discussions about fair travelling model.

\section{Project activity for achieve the stated objective}

The activities carried out within the project were:

1. Desk research, aimed to collect theoretical references as well as best practices, constraints, and barriers related to the mobility of people affected by behavioral disorders/disturbances.

2. Fair traveling model that includes:

- Travel issues corresponding to the different types of children disorders/disturbances;

- Needs of families with children affected by behavioral disorders/disturbances when they travel;

- Educational supports that can facilitate the travels of these families.

3. Model discussion involving in each participating countries a panel of parents and educators.

Accordingly, partner performed the desk research in their countries collecting various available online and offline sources (such as scientific literature, reports, statistics, recommendations) checking for their reliability.

The term "behavioral disorders" is usually understood to mean difficulties in upbringing and violation of socially accepted norms in human relationships. These difficulties and norms may depend on each individual person encountering them. Some consider behavioral disorder as a behavioral disorder and associate it with aggressive behavior. Little attention is paid to passive activity and depressive states as behavioral disorders, although they affect one's own life and successful 
integration with others (Bethere D., Līdaka A., Plostniece A., Ponomorjova J., Striguna S., 2013).

Behavioral disorders are related to the age of the children:

- childhood-onset CDs ( 7\%) (more common in boys) show more aggressive behavior, disproportionate delinquency, and persistence as the child grows.

- Character remains the same as other options become available as they grow.

Investigating human behavior and timely detection and prevention of negative behaviors can be considered essential in any society. This is particularly important for countries facing socio-economic crises, as is currently the case in Latvia. In Latvia, the issue of reducing the negative manifestations of behavior is topical, as they significantly influence the educational attainment of students and the quality of their upbringing or preparation for life in society.

Currently, researchers in different countries (Bethere, Līdaka, Plostniece, 2013) characterize the causes of negative behavior and classify them by focusing on the functional manifestations of behavior.

The result of the desk research is a collection of theoretical references as well as best practices, constraints, and barriers related to the mobility of people affected by behavioral disturbs.

The Figure 1 shows the scope of behavioral disorders/disturbances.

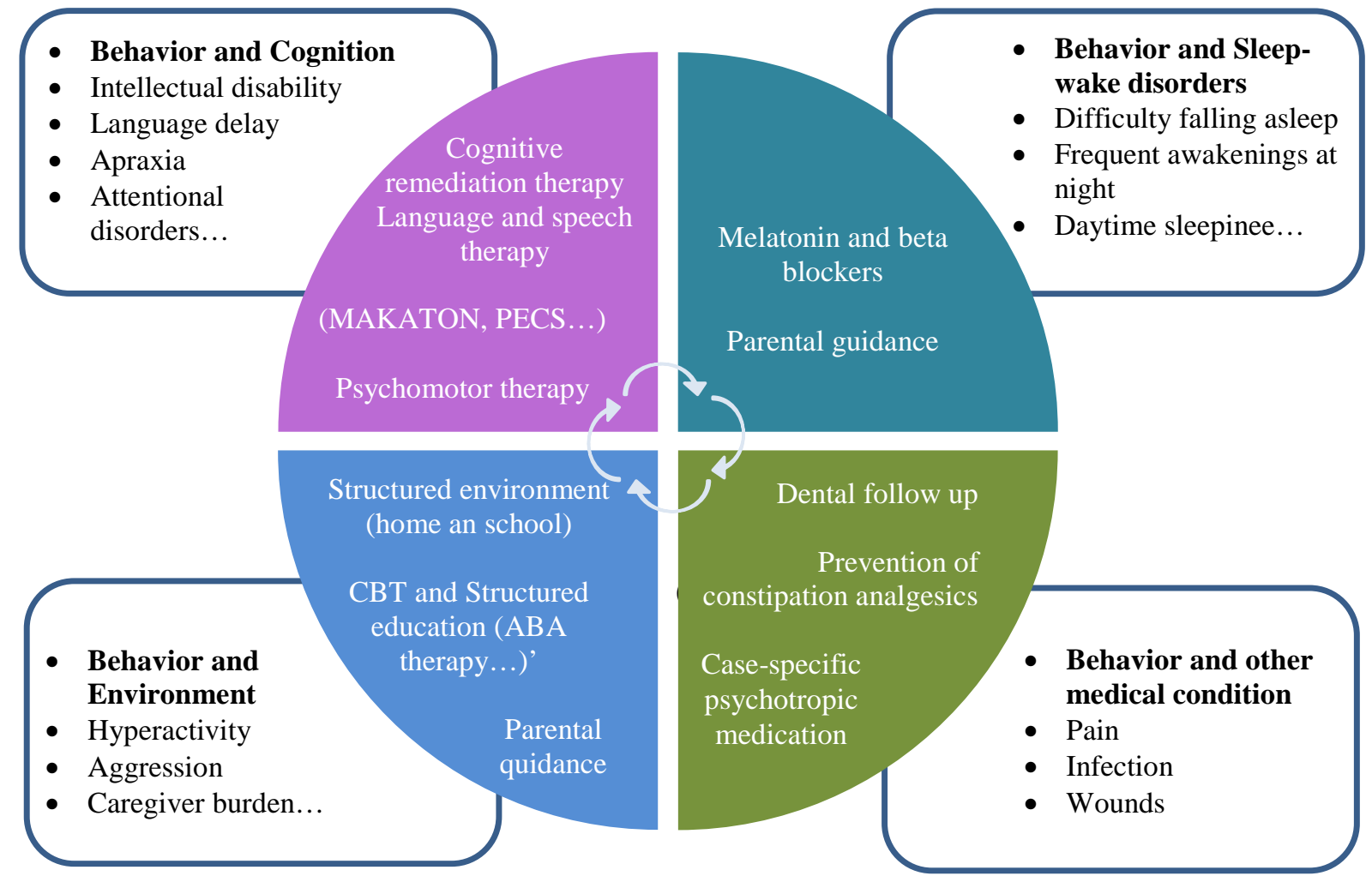

Figure 1 Behavioral disorders/disturbances (Poisson et al., 2015) 
Disabled adult people are active participants society, making a significant contribution to its development. Medical model instead, it defines disability through the lens of health, perceiving it as a disease, which is under the control of doctors and rehabilitation specialists. Among adults disabled people declaring their stay outside the place of residence, only $30 \%$ took part in tourist and leisure trips, $28 \%$ in health care, while most trips concerned visits of relatives and friends. Due to the type of disease, people with cardiovascular diseases travel most often (21\%), while the least people with mental retardation and mentally ill (15\%), as well as people with hearing impairment (Milewska, 2008).

There are also several key considerations that emerged from informal interviews with project members, parents of children with behavioural disturbs are presented in below in Table 1.

Table 1 A list of subjects that, usually, interact in a travel of families with children affected by behavioral disturbs (project source)

\begin{tabular}{|c|c|}
\hline Travel preparation (e.g. travel agencies) & $\begin{array}{l}\text { Travel activity (e.g., transportations, } \\
\text { accommodations, etc.). }\end{array}$ \\
\hline $\begin{array}{l}\text { Parents of children with disabilities may approach } \\
\text { travel with elevated levels of stress, because } \\
\text { children with disability need more assistance and the } \\
\text { continuous attention of their parents while traveling, } \\
\text { as compared to typically developing children. }\end{array}$ & $\begin{array}{l}\text { Travel activities are linked to external or } \\
\text { circumstantial factors. These factors are } \\
\text { flexible and adaptable for families to } \\
\text { participate? }\end{array}$ \\
\hline $\begin{array}{l}\text { The travel preparation for a trip varies depending on } \\
\text { the type of disability. }\end{array}$ & $\begin{array}{l}\text { Tourism industry provides relevant and } \\
\text { meaningful services to these families? }\end{array}$ \\
\hline $\begin{array}{l}\text { Are travel agencies aware of the specific types of } \\
\text { information that the parents of a disabled child are } \\
\text { likely to need? }\end{array}$ & $\begin{array}{l}\text { Are there child-friendly programs and } \\
\text { experiential activities that are oriented } \\
\text { toward that goal adaptive and accessible } \\
\text { sports and recreational activities? } \\
\text { Activities which are modified or } \\
\text { designed to allow children with }\end{array}$ \\
\hline $\begin{array}{l}\text { How families could have access to specific and } \\
\text { meaningful information they need for every } \\
\text { destination? }\end{array}$ & $\begin{array}{l}\text { disabilities to participate and may thus } \\
\text { attract these families? }\end{array}$ \\
\hline $\begin{array}{l}\text { Parents need information regarding their destination } \\
\text {-specific kind of food they would need } \\
\text {-specific medicine } \\
\text {-means of transport } \\
\text {-accessibility (e.g. of museums) } \\
\text {-special health institutes } \\
\text {-special therapies }\end{array}$ & $\begin{array}{l}\text { Do service providers have positive } \\
\text { attitudes and suitable communication } \\
\text { skills? }\end{array}$ \\
\hline $\begin{array}{l}\text { Parents have to know how to prepare their child and } \\
\text { how they will be prepared for the new physical and } \\
\text { social environment of the country they will visit. }\end{array}$ & $\begin{array}{l}\text { Are there specific and aware officers in } \\
\text { every embassy that would inform } \\
\text { families for special services and needs in } \\
\text { the country that the family visits? }\end{array}$ \\
\hline
\end{tabular}




\section{Fair traveling model}

Individuals with behavioral disturbances may experience various problems while traveling. Individuals are stressed during travel, a sudden triggering noise, traffic and many other travel factors can cause individuals with autism to have problems. During the journey, he may show temper tantrums, and may display problem behaviors such as crying crises or similar mood disorders.

On the basis of the desk research results, the fair traveling model for families with children with behavioral disorders/disturbances has been developed, identifying its most important dimensions, needs, and issues these families can experience in traveling.

The model also refers to motivational, cognitive, situational, and dispositional factors that determine the interaction among subjects involved in traveling activities.

The primary components of the model are (Figure 2):

- Transportation

- Accommodation

- Restaurants

- Leisure

- $\quad$ Public services

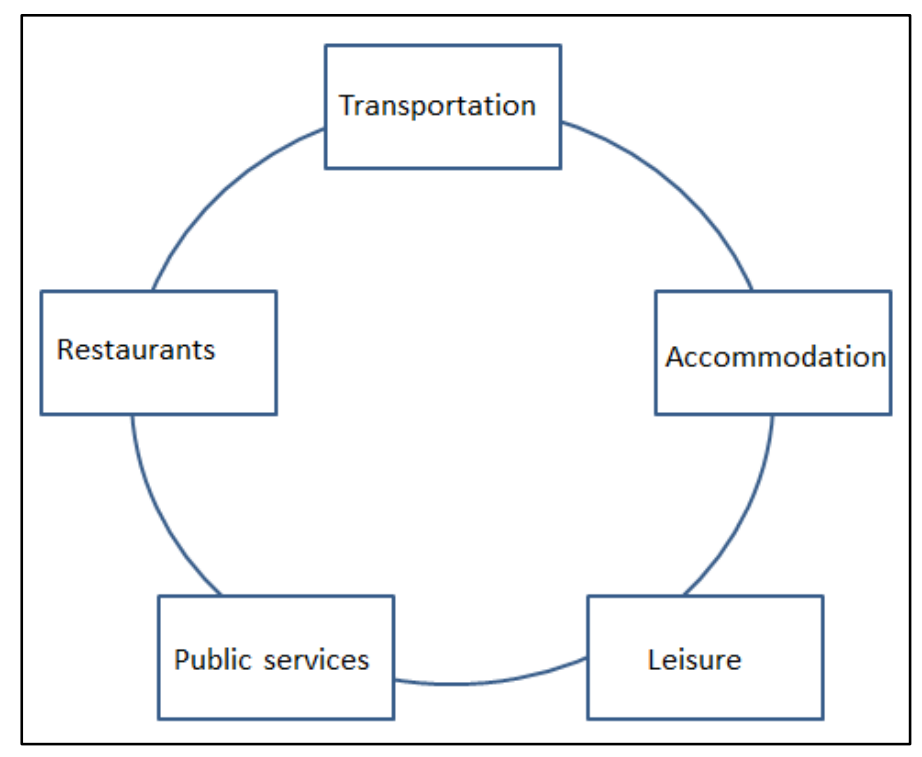

Figure 2 Traveling components (project source)

Note that families can take advantage of new technologies to access to services. The relational issues include communication difficulties with:

- $\quad$ Residents: exclusion, due to the distrust and ignorance of the problems of people with ASD; 
- Other travelers: exclusion, due to the distrust and ignorance of the problems of people with ASD;

- Public services: lack of supportive policies and/or specific services;

- Traveling service providers: lack of interest to create specific services. The main traveling impact/issues for families with children with ASD are:

- changes in routine;

- $\quad$ tackling unexpected events;

- $\quad$ Finding the appropriate accommodation structures;

- Manage the children behavior;

- Interacting with normal people;

- Crowd;

- $\quad$ new noises and sights.

Planning travel is an action that encompasses all the travel components and can be affected by traveling relationships. When a family plans travel should define a strategy to minimize the primary impacts/issues that can occur.

To achieve this goal, it is important to define travel in all its aspects. On this purpose, can be useful the following travel descriptors: trip origins, trip destinations, distance, travel time, travel duration, trip purpose, mode for trip and number of persons.

\section{The Results of Focus Discussions}

4 parents having children with behavioral disorders and 3 educators from each project partner country participated in the focus discussions.

Focus discussions were held in the partner countries with parents with children with developmental disabilities, their traveling experiences, the problems they encountered, and educators. 3 basic questions were asked:

1. What are the main traveling issues?

2. What are the policies of subjects involved in traveling services?

3. What are the public and volunteers' support?

Summary of the results of parents' focus discussions. When reading the content of the answers, it was concluded that it identifies the following concepts related to the travelling problems: transport, specifics of the child's special needs, stress, attitude, infrastructure, lack of conformity of services, need for support/volunteer.

Parents point out that the biggest problem is that traveling causes stress to the child due to changing daily routine, habitual environment, and interruption of the child's education. 
In order to travel, personal transport is being used (..we go on trips but only with our car; Due to the specificity of my daughter's illness, we try to avoid public transport. We use it in exceptional cases). The choice is determined by the following:

1) Child's special needs, such as
a) Specific behavior;
b) Incontinence;
c) Need for special equipment.

2) Lack of conformity of public transport.

3) The attitude of surrounding people is often negative, despite conversations about an inclusive society for years: others do not understand the behavior of a child with special needs.

Summary of the results of educators' focus discussions. When reading the content of the answers, it was concluded that it identifies the following concepts related to the travelling problems: specifics of the child's special needs, stress, attitude, infrastructure, lack of conformity of services, parents' readiness to travel, and need for improvement in various fields.

Just like parents, educators emphasize that traveling is influenced by a child's special needs, his/her behavior while traveling.

Educators' responses also highlight the negative attitudes of surrounding people (The vast majority of people in the community are insensitive to people with special needs. (..)The negative behaviors and reactions people show towards individuals with autism are the biggest problems faced by families with children with autism (...)When children react differently, the attitude of people and their attitudes towards them is extremely disturbing for families) and lack of conformity of available travel services to meet the traveling needs of children with special needs and their parents, even denial to provide the services.

In the focus discussions, educator focuses on the following:

1) inadequate public education about children with special needs and the need to improve it;

2) the need to improve the services provided by developing infrastructure, improving the service providers' competence in dealing with children with special needs, and engaging volunteers.

Both parents and educators focus on the child's special needs, attitudes of surrounding people, and conformity of the services available. However, educators pay a lot of attention also on the readiness of parents themselves to travel with their child with special needs. Educators emphasize that parents are often not ready to travel and avoid traveling (Families with children affected by ASD generally avoid travelling and they are afraid of their children's unpredictable behaviors). Traveling creates extra stress not only for a child but also for parents, but it can be reduced if parents are well prepared for the trip (There is a chance 
for them to get excited. but this depends on the attitude and the proper preparation that the parents will make for the child to feel safe). This highlights the need to educate not only the public and service providers, but also parents.

\section{Conclusions}

The desk research showed that, in the partner countries, there are the same issues for these families. They are changes in routine; tackling unexpected events; finding the appropriate accommodation structures and manage the children behavior.

Parents having children with behavioral disorders face a variety of travelingrelated problems such as attitude of other people, transportation problems, lack of conformity of services and others. These results in stress for both parents and a child, and his/her behavior can become unpredictable. Traveling opportunities are also determined by the child's specific special needs.

It is important to understand how to help parents, other people involved in the trip, and travel service providers in order to have a positive outcome for all.

One of such options is education. Educational activities must be first and foremost aimed at educating society as a whole, because the attitude of surrounding people is often negative, despite conversations about an inclusive society for years: others do not understand the behavior of a child with special needs.

In an inclusive society, everyone should have the same rights, including the rights to leisure and travel. There are cases where parents having children with special needs, for whatever reason, provoke this situation. This may be due to their stress and their own inadequate preparation for the trip, and more importantly - inadequate preparation of their child with special needs. Changes in usual environment and daily rhythm cause anxiety, stress, and as a result the child's behavior becomes unpredictable.

Parents' education is needed to help them to plan their trip, choose appropriate accommodations, transportation, attractions, etc., prepare themselves for the trip psychologically, and prepare a child for it. Surrounding people are not always able to understand the situation, they have to be communicated with and, if necessary, asked for help, indicating what kind of help is needed. Parents' unpreparedness and stress can hinder successful communication and deepen the problem.

It is necessary to educate travel service providers as well: how to plan a route and time if there are parents with children with behavior disorders in the group, and how to support parents in problem situations. Before traveling, parents may also need to fill out a detailed information sheet about their child, indicating very specific needs, such as the time to visit the toilet and have lunch. 
Model for fair traveling of families with children affected by behavioral disturbs

\section{Acknowledgement}

Co-funded by the Erasmus+ Programme

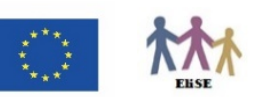

This article is supported by the Erasmus+ Strategic partnership program project "Eliminating Social Exclusion” EliSE Nr. 2019-1-LV01-KA204-060427

\section{References}

Bethere D., Līdaka A., Plostniece A., Ponomorjova J., \& Striguna S., (2013). Metodiskais materiāls pedagogiem darbam ar izglītojamiem, kuriem ir uzvedības traucējumi. https://visc.gov.lv/specizglitiba/dokumenti/metmat/esfpr/VISC\%202.2\%20\%20metod\%20mater\%20pedagogiem\%20-\%20uzvedibas\%20traucejumi.pdf

Buttimer, J., \& Tierney, E. (2005). Patterns of leisure participation among adolescents with a mild intellectual disability. Journal of Intellectual Disability, 9(1),25e42.

Milewska, M. (2008) Turystyka osób niepetnosprawnych w Europie $i$ w Polsce, in. Stasiak A. (ed.), Rola krajoznawstwa i turystyki w życiu osób niepełnosprawnych. Wydawnictwo PTTK Kraj. Warszawa.

Poisson, A., Nicolas, A., Cochat, P., Sanlaville, D., Rigard, C., de Leersnyder, H., ... \& Demily, C. (2015). Behavioral disturbance and treatment strategies in Smith-Magenis syndrome. Orphanet journal of rare diseases, 10(1), 111. 